\title{
IDENTIFIKASI DAN ANALISIS KANDUNGAN MAKRONUTRIEN GLUKOMANAN UMBI PORANG (Amorphophallus onchophyllus)
}

\author{
Bekti Nugraheni $^{(*)}$, Anastasia Setyopuspito $\mathbf{P}^{1)}$, Yustisia Dian Advistasari ${ }^{1)}$ \\ ${ }^{1}$ Sekolah Tinggi Ilmu Farmasi, Yayasan Pharmasi Semarang \\ Jl. Letjend Sarwo Edie Wibowo KM I Plamongansari Semarang \\ e-mail: bn.nugraheni@gmail.com
}

\section{INTISARI}

Tujuan dari penelitian ini adalah identifikasi dan analisis kandungan makronutrien glukomanan umbi porang (Amorphophallus onchophyllus). Penelitian ini dilakukan 3 tahap yaitu: ekstraksi, identifikasi dan uji makronutrien glukomanan umbi porang. Sebelum diekstraksi, umbi porang dihilangkan dari kandungan oksalatnya dengan 2\% air jeruk nipis: 5\% kapur sirih, selanjutnya diekstraksi menggunakan metode ultrasonik. Identifikasi glukomanan dilakukan menggunakan instrumentasi Fourier Transform Infra Red (FTIR) dan uji makronutrien meliputi: lemak (Soxhletasi); protein (Kjedahl); serat (Soxhletasi); dan karbohidrat (Metode Anthrone). Hasil identifikasi menggunakan Fourier Transform Infra Red (FTIR) menunjukkan adanya $\beta$-piranosa pada bilangan gelombang $900-810 \mathrm{~cm}^{-1}$. Gugus $\mathrm{C}=\mathrm{O}$ pada asetil pada 1726 $\mathrm{cm}^{-1}$. Daerah $870 \mathrm{~cm}^{-1}$ dan $800 \mathrm{~cm}^{-1}$ menunjukkan senyawa $\beta$-glikosidik dan $\beta$-manosidik. Gugus eter C-O ditunjukkan di daerah 1260-1200 $\mathrm{cm}^{-1}$, sedangkan untuk alkohol C-O pada daerah $1050 \mathrm{~cm}^{-1}$ menunjukan ikatan C-O pada alkohol. Pada $2925 \mathrm{~cm}^{-1}$ menunjukan C-H, sedangkan pada $3000-3700 \mathrm{~cm}^{-1}$ gugus O-H. Kadar makronutrien glukomanan umbi porang meliputi: lemak sebesar $0,50 \%$, protein sebesar $1,05 \%$, serat sebesar 22,34\%, dan karbohidrat sebesar 31,33\%.

Kata kunci: Umbi Porang, Glukomanan, FTIR, analisis makronutrien

\begin{abstract}
The purpose of this study is identification and analysis of the macronutrient glucomannan from porang tuber (Amorphophallus onchopyllus). The stages done in this research are extraction, identification, and macronutrient analysis of glucomannan of the porang tuber. Prior to extraction, the oxalic acid was removed from porang tuber using mixture of $2 \%$ lime juice and $5 \%$ lime, then the glucomannans was extracted using ultrasonic method. The glucomannan then was identified using Fourier transform infra red spectrometer (FTIR) instrument and macronutrient analyzer such as Soxhlet method for fats and fibers, Kjedahl method for protein, and Antrone method for carbohydrates. The results of identification using FTIR showed the presence of $\beta$-pyranose at wave numbers of $900-810 \mathrm{~cm}^{-1}$. The carbonyl on on acetyl group was found at $1726 \mathrm{~cm}^{-1}$. The area between $870-800 \mathrm{~cm}^{-1}$ showed the $\beta$-glycosidic and $\beta$-manosidic compounds. The $\mathrm{C}-\mathrm{O}$ ether group was shown in the area of $1260-1200 \mathrm{~cm}^{-1}$, while for $\mathrm{C}-\mathrm{O}$ alcohol was shown in the area of $1050 \mathrm{~cm}^{-1}$ showed the C-O bond in alcohol. At $2925 \mathrm{~cm}^{-1}$ it showed C-H, while at $3000-3700 \mathrm{~cm}^{-1} \mathrm{O}-\mathrm{H}$ group. The levels of porang glucomannan macronutrients included fat at $0.50 \%$, protein at $1.05 \%$, fiber at $22.34 \%$, and carbohydrates at $31.33 \%$.
\end{abstract}

Key word: Porang tuber, glucomannan, FTIR, macronutrient analysis.

Corresponding author:

Bekti Nugraheni

Sekolah Tinggi Ilmu Farmasi, Yayasan Pharmasi Semarang

Jl. Letjend Sarwo Edie Wibowo KM I Plamongansari Semarang.

e-mail: bn.nugraheni@gmail.com 


\section{PENDAHULUAN}

Umbi porang (Amorphophallus oncophyllus) termasuk tanaman umbi famili Araceae yang mengandung kadar glukomanan yang cukup tinggi (15-64\% basis kering). Katsuraya dkk (2003) menyebutkan bahwa glukomanan merupakan makanan dengan kandungan serat larut air yang tinggi, rendah kalori dan bersifat hidrokoloid yang khas. Glukomanan memiliki gugus asetil setiap 10-19 unit gugus karbon pada posisi C2, C3 dan C6. Gugus asetil tersebut berperan pada sifat fisikokimia glukomanan seperti sifat kelarutan glukomanan dalam air panas maupun air dingin.Struktur kimia glukomanan dapat dilihat pada Gambar 1.

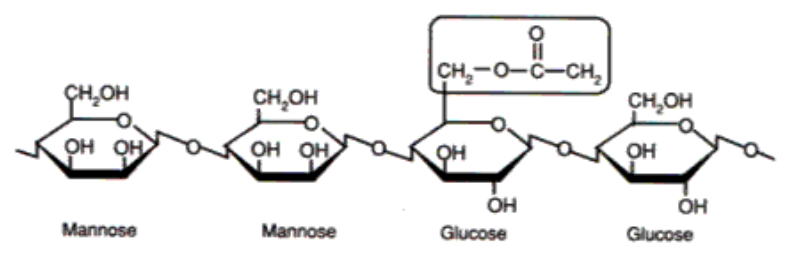

Gambar 1. Struktur Kimia Glukomanan

Glukomanan di beberapa negara Asia lainnya seperti Jepang dan Cina yang umumnya diperoleh dari umbi tanaman Amorphophallus onchophyllus mempunyai banyak kegunaan salah satunya anti diabetes tipe 2 (Sande dkk, 2009), selain itu dapat dikonsumsi oleh penderita hipertensi dan kolesterol. Selain digunakan untuk pengobatan suatu penyakit, glukomanan porang juga dapat digunakan sebagai Bahan Tambahan Makanan (BTM) seperti pada mie dan pasta dikarenakan kemampuan glukomanan yang sangat besar dalam mengikat air (Mulyono dkk, 2009).

\section{METODE PENELITIAN Design Penelitian}

Umbi Porang (Amorphophallus onchophyllus) memiliki kandungan glukomanan yang tinggi, untuk memperoleh glukomanan tersebut perlu dilakukan proses ekstraksi. Sebelum dilakukan ekstraksi, umbi porang (chips) dihilangkan terlebih dahulu kalsium oksalatnya menggunakan air jeruk nipis : kapus sirih. Kemudian dikeringkan dan diserbukkan, hasilnya adalah tepung umbi porang. Tepung umbi porang dilakukan ekstraksi dengan ultasonik. Hasil residu adalah glukomanan, dikeringkan dan diserbukkan. Glukomanan dilakukan identifikasi menggunakan FTIR dan uji makronutrien (lemak, protein, serat dan karbohidrat).

\section{Bahan Penelitian}

Umbi porang (Amorphophallus onchophyllus), n-heksan, aquadest, jeruk nipis, kapur sirih, $\mathrm{NH}_{4} \mathrm{Cl}$, petroleum eter, $\mathrm{H}_{2} \mathrm{SO}_{4}, \mathrm{Na}_{2} \mathrm{SO}_{4}, \mathrm{HgO}, \mathrm{NaOH}, \mathrm{Na}_{2} \mathrm{~S}_{2} \mathrm{O}_{3}, \mathrm{HCl}$, Pereaksi Anthrone, indikator metil jingga, asam borat.

\section{Alat Penelitian}

Fourier Transform Infra Red (FTIR), Spektrofotometer Visibel, Soxhlet, Labu Kjedahl, Alat-alat gelas: beker glass, erlenmeyer, pipet volume, botol timbang.

\section{Pembuatan Serbuk Umbi Porang}

Umbi porang dikupas kulitnya dan diiris. Irisan dicuci dengan air mengalir hingga bersih. Kemudian dihilangkan getahnya menggunakan n-heksana, dan dicuci kembali dengan air mengalir dan selanjutnya dilakukan perendaman dengan 2\% jeruk nipis : $5 \%$ kapur sirih selama 6 jam dan dikeringkan pada panas matahari langsung. Irisan yang telah kering kemudian dilakukan penggilingan dan diayak dengan ayakan mesh 60.

\section{Penyiapan Sampel glukomanan}

Serbuk umbi porang ditimbang 4 gram dan dimasukkan ke dalam beaker glass. Serbuk tersebut ditambahkan $50 \mathrm{~mL} \mathrm{NH} \mathrm{NH}_{4} \mathrm{Cl} 0,1 \%$ dan $100 \mathrm{~mL}$ air hangat $\left(75^{\circ} \mathrm{C}\right)$. dilakukan pengadukan menggunakan hot plate stirer selama 30 menit. Endapan sampel dipisahkan dengan sentrifus 2000 rpm selama 30 menit dan diambil filtratnya. Filtrat yang didapat kemudian dimasukkan dalam Erlenmeyer dan ditambahkan $150 \mathrm{~mL}$ etanol $96 \%$ dan diultrasonik. Selanjutnya, lendir yang didapat disaring dengan kertas saring menggunakan pompa vakum. Lendir yang dihasilkan 
kemudian dikeringkan dalam lemari pengering selama 24 jam dan dilakukan penimbangan hingga bobot konstan.

\section{Identifikasi Glukomanan}

Identifikasi glukomanan ditentukan menggunakan instrumentasi Fourier Transform Infra Red (FTIR), dengan menentukan gugus spesifik dari glukomanan umbi porang.

\section{Uji makronutrien glukomanan}

Uji karakteristik glukomanan (analisa kadar air, lemak, protein, serat, karbohidrat)

a. Kadar air

Ditimbang seksama 1 gram glukomanan dan diletakkan didalam krus yang telah diketahui beratnya, kemudian dimasukkan kedalam oven pada suhu $105^{\circ} \mathrm{C}$ selama 1 jam. Setelah itu didinginkan dalam desikator selanjutnya ditimbang sampai berat tetap (Yenrina, 2015)

b. Kadar Lemak

Ditimbang seksama 2 gram bahan yang telah dihaluskan. Kemudian dicampur dengan pasir yang telah dipijarkan sebanyak 8 gram dan masukkan ke dalam tabung ekstraksi soxhlet. Di alirkan air pendingin melalui kondensor. Tabung ekstraksi dipasang pada alat soxhlet dengan pelarut eter secukupnya selama 4 jam. Setelah residu dalam tabung diaduk, ekstraksi dilanjutkan lagi selama 2 jam dengan pelarut yang sama. Petroleum eter yang telah mengandung lemak dipindahkan ke dalam botol timbang yang bersih dan diketahui beratnya kemudian diuapkan dengan penangas air sampai agak pekat. Pengeringan diteruskan dalam oven $100^{\circ} \mathrm{C}$ sampai berat konstan. Berat residu dalam botol timbang dinyatakan sebagai berat lemak.

c. Kadar protein

Sebanyak 10 gram sampel dimasukkan kedalam labu takar $100 \mathrm{~mL}$ dan diencerkan dengan aquades sampai tanda batas. $10 \mathrm{~mL}$ larutan tersebut dimasukkan dalam labu kjedahl $500 \mathrm{~mL}$ dan ditambahkan $10 \mathrm{~mL} \mathrm{H} \mathrm{H}_{2} \mathrm{SO}_{4}$ pekat. Kemudian ditambahkan 5 gram campuran $\mathrm{Na}_{2} \mathrm{SO}_{4}-\mathrm{HgO}$ (20:1) untuk katalisator. Didihkan sampai jernih dan dilanjutkan pendidihan 30 menit. Setelah dingin ditambahkan $140 \mathrm{ml}$ aquades dan $35 \mathrm{~mL}$ larutan $\mathrm{NaOH}-\mathrm{Na}_{2} \mathrm{~S}_{2} \mathrm{O}_{3}$. Selanjutnya dilakukan destilasi dengan cara destilat ditampung sebanyak $100 \mathrm{~mL}$ dalam Erlenmeyer yang berisi $25 \mathrm{~mL}$ larutan jenuh asam borat dan indikator metil merah. Dilakukan titrasi dengan $\mathrm{HCl} 0,02 \mathrm{~N}$. dihitung $\mathrm{N}$ total atau \% protein (Yenrina, 2015).

d. Kadar Serat

Sebanyak 2 gram bahan kering dan diekstraksi lemaknya dengan soxhlet. Kemudian dipindahkan kedalam Erlenmeyer $600 \mathrm{~mL}$, ditambah $200 \mathrm{~mL} \mathrm{H}_{2} \mathrm{SO}_{4}$ 0,255 N dan ditutup dengan pendingin balik. Didihkan selama 30 menit. Suspensi disaring menggunakan kertas saring, kemudian residu dalam kertas saring dicuci dengan aquades mendidih sampai tidak bersifat asam (di uji dengan kertas lakmus). Selanjutnya residu dipindahkan dari kertas saring kedalam Erlenmeyer dan dicuci dengan NaOH 0,313 N sebanyak $200 \mathrm{~mL}$. Didihkan dengan pendingin balik selama 30 menit. Lalu disaring dengan kertas saring yang diketahuhi beratnya sambil dicuci dengan $\mathrm{K}_{2} \mathrm{SO}_{4} 10 \%$. Kemudian dicuci lagi dengan aquades mendidih dan $15 \mathrm{~mL}$ alkohol 95\% (Yenrina, 2015).

e. Kadar karbohidrat metode anthrone

Penetapan kadar karbohidrat dengan menambahkan $1 \mathrm{~mL}$ larutan ekstrak sampel konsentrasi 0,2 $\mathrm{mg} / \mathrm{mL}$ dengan $5 \mathrm{~mL}$ pereaksi anthrone di dalam lemari asam. Kemudian tutup tabung dan gojok larutan agar tercampur rata. Larutan kemudian dipanaskan di atas waterbath dengan suhu $100^{\circ} \mathrm{C}$ selama 12 menit, setelah itu didinginkan dan ditunggu hingga OT yang didapat sebelumnya. Kemudian larutan dibaca absorbansinya di spektrofotometer visible pada panjang gelombang maks yang didapat (623,8 nm) (Anonim, 1999).

\section{HASIL DAN PEMBAHASAN}

Pada penelitian ini, umbi porang dihilangkan getahnya menggunakan n-heksana, dan dicuci kembali dengan air mengalir dan perendaman dengan 2\% jeruk nipis : 5\% kapur sirih selama 6 Jam. Perendaman bertujuan untuk menghilangkan oksalat yang ada didalam umbi porang, karena kristal oksalat dapat menyebabkan penyumbatan pada saluran kencing atau batu ginjal. Kemudian dilakukan pengeringan dalam almari pengering suhu $50^{\circ} \mathrm{C}$ selama 2 hari, bertujuan untuk mengurangi kadar air dalam umbi, selain itu dapat mengurangi terjadinya reaksi enzimatik yang 
diperantarai oleh adanya air, sehingga simplisia tersebut tahan dalam penyimpanan. Hasil akhirnya adalah glukomanan porang. Glukomanan porang yang dihasilkan, diserbukkan kemudian diayak dengan ayakan 60 untuk mendapatkan serbuk yang ukurannya seragam. Hal ini berkaitan dengan proses penarikan senyawa aktif oleh cairan penyari.

Hasil uji kadar air tepung glukomanan porang sebesar 4,90\%, hal ini berarti kadar air tersebut memenuhi syarat kadar air tepung < 14,5\% menurut SNI 3751 (2009), sehingga masuk kadar air tepung yang baik. Hasil akhirnya adalah glukomanan porang. Glukomanan porang yang dihasilkan, diserbukkan kemudian diayak dengan ayakan 60 untuk mendapatkan serbuk yang ukurannya seragam. Hal ini berkaitan dengan proses penarikan senyawa aktif oleh cairan penyari.

Pada analisis FTIR, menunjukkan bilangan gelombang glukomanan porang kuning pada $4000-400 \mathrm{~cm}^{-1}$. Puncak khas $\beta$-piranosa terlihat pada bilangan gelombang $900-810 \mathrm{~cm}^{-1}$. Gugus karbonil pada asetil ditunjukkan pada $1726 \mathrm{~cm}^{-1}$ (An dkk., 2010). Daerah $870 \mathrm{~cm}^{-1}$ dan $800 \mathrm{~cm}^{-1}$ menunjukkan senyawa $\beta$-glikosidik dan $\beta$-manosidik (Widjanarko dkk., 2011). Gugus eter C-O ditunjukkan oleh puncak di daerah 1260-1200 $\mathrm{cm}^{-1}$, sedangkan untuk alkohol C-O pada daerah $1050 \mathrm{~cm}^{-1}$ menunjukan ikatan C-O pada alkohol. Puncak pada bilangan gelombang $2925 \mathrm{~cm}^{-1}$ menunjukan regangan gugus $\mathrm{C}-\mathrm{H}$, sedangkan puncak pada $3000-3700 \mathrm{~cm}^{-1}$ menunjukkan regangan gugus $\mathrm{O}-\mathrm{H}$ yang terlihat pada struktur glukomanan (Gambar 2). Hal ini menunjukkan bahwa sampel hasil ektraksi tersebut adalah glukomanan dari umbi porang (Amorphophallus onchophyllus).

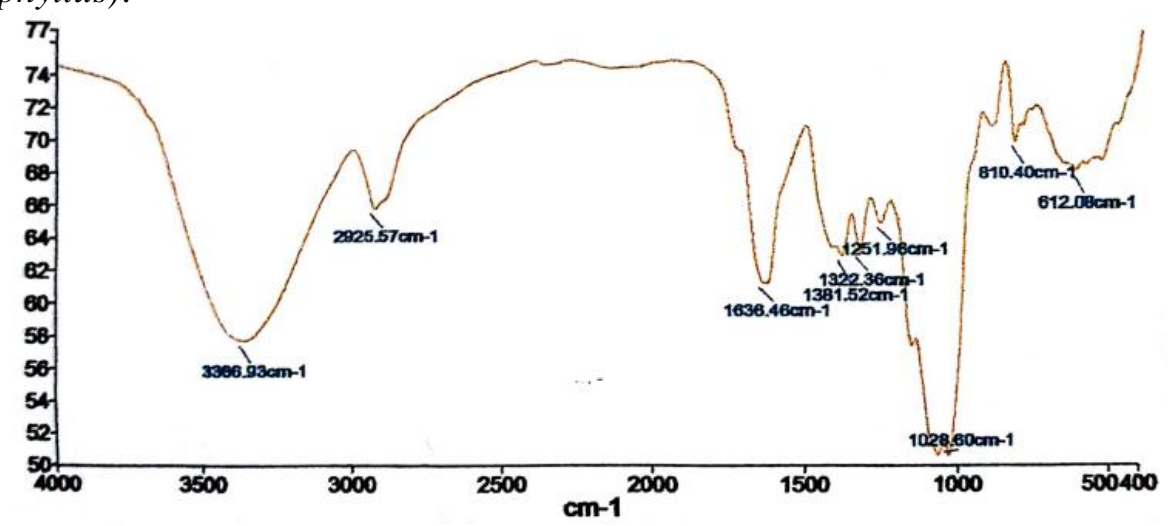

Gambar 2. Spektrum Infrared glukomanan hasil ekstraksi

Selanjutnya dilakukan uji kadar makronutrien. Uji makronutrien yang dilakukan meliputi lemak, protein, serat dan karbohidrat. Uji lemak dilakukan dengan cara destruksi basah terlebih dahulu kemudian dilakukan soxhletasi, uji protein menggunakan metode biuret. Uji serat menggunakan soxhletasi, dan uji karbohidrat dilakukan dengan metode Anthrone.

Tabel 1. Hasil Parameter Uji Makronutrien Glukomanan Porang

\begin{tabular}{cc}
\hline Parameter Uji & Persentase (\%) \\
\hline Lemak & 0,50 \\
Protein & 1,05 \\
Serat & 22,34 \\
Karbohidrat & 31,33 \\
\hline
\end{tabular}

Uji makronutiren, bertujuan untuk melihat kandungan tepung porang yang meliputi: karbohidrat, lemak dan protein. Uji lemak dilakukan dengan cara destruksi basah terlebih dahulu kemudian dilakukan soxhletasi, uji protein menggunakan metode biuret, uji serat dilakukan menggunakan sokhletasi sedangkan, uji karbohidrat dilakukan dengan metode Anthrone.

Pengujian lemak dalam sampel tepung porang menggunakan metode soxhletasi. Prinsip Soxhletasi ialah ekstraksi menggunakan pelarut yang selalu baru sehingga terjadi ekstraksi kontiyu dengan jumlah pelarut konstan dengan adanya pendingin balik. Proses ekstraksi lemak kasar dilakukan selama 6 jam. Setelah proses ekstraksi selesai, pelarut dan lemak dipisahkan melalui 
proses penyulingan dan dikeringkan. Hasil kadar lemak pada tepung porang diperoleh sebanyak $0,50 \%$.

Metode Kjeldahl, merupakan metode sederhana untuk penetapan nitrogen total pada asam amino, protein, dan senyawa yang mengandung nitrogen. Sampel didestruksi dengan asam pekat (asam sulfat), dan dikatalis dengan katalisator yang sesuai sehingga menghasilkan ammonium sulfat. Setelah pembebasan dengan alkali kuat, ammonia yang terbentuk disuling uap secara kuantitatif ke dalam larutan penyerap dan ditetapkan secara titrasi. Tahap destilasi, dengan menambahkan basa berlebih pada campuran acid digestion untuk mengkonveksi $\mathrm{NH}_{4}{ }^{+} \mathrm{ke} \mathrm{NH}_{3}$, diikuti dengan mendidihkan dan mengkondensasi gas $\mathrm{NH}_{3}$ ke larutan penerima (asam borat dalam jumlah berlebih). Proses titrasi, apabila penampung destilat menggunakan asam klorida, maka sisa asam klorida akan bereaksi dengan ammonia dititrasi dengan $\mathrm{NaOH}$ dan ditandai dengan perubahan warna larutan menjadi merah muda. Pada penelitian ini, destilatnya menggunakan asam borat, sehingga dititrasi dengan $\mathrm{HCl}$, sehingga banyaknya asam borat yang bereaksi dengan ammonia dapat diketahui. Akhir titrasi ditandai dengan perubahan warna larutan dari hijau menjadi merah muda.

Uji karbohidrat menggunakan metode Anthrone. Anthrone, $\mathrm{C}_{6} \mathrm{H}_{4} \mathrm{COC}_{6} \mathrm{H}_{4} \mathrm{CH}_{2}$, adalah turunan dari anthroquinone. Metode Anthrone menggunakan instrumentasi Spektrofotometer UV. Prinsipnya, anthrone (9,10-dihidro-9-oksanthracen) merupakan hasil reduksi anthraquinon, anthrone bereaksi secara spesifik dengan karbohidrat dalam asam sulfat pekat menghasilkan warna biru kehijauan yang khas. Reaksi pembentukan anthrone dapat dilihat pada Gambar 3.

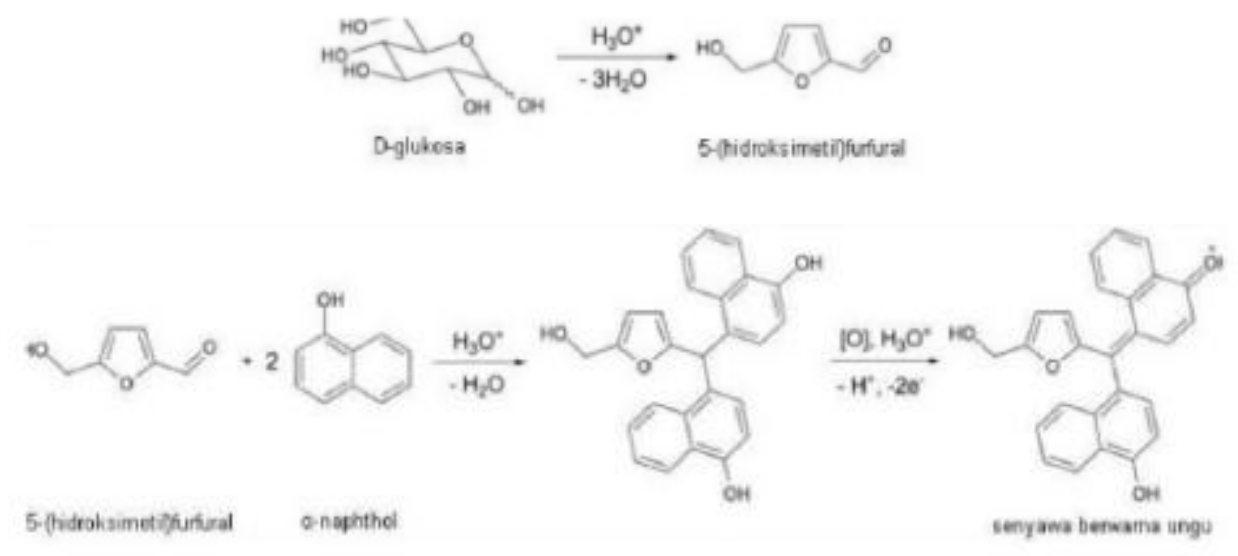

Gambar 3. Reaksi Pembentukan Anthrone

\section{KESIMPULAN}

Adapun kesimpulan dari penelitian ini adalah identifikasi glukomanan menggunakan FTIR menunjukkan adanya $\beta$-piranosa pada bilangan gelombang $900-810 \mathrm{~cm}^{-1}$. Gugus $\mathrm{C}=\mathrm{O}$ pada asetil pada $1726 \mathrm{~cm}^{-1}$. Daerah $870-800 \mathrm{~cm}^{-1}$ menunjukkan senyawa $\beta$-glikosidik dan $\beta$-manosidik. Gugus eter C-O ditunjukkan di daerah 1260-1200 $\mathrm{cm}^{-1}$, sedangkan untuk alkohol C-O pada daerah 1050 $\mathrm{cm}^{-1}$ menunjukan ikatan $\mathrm{C}-\mathrm{O}$ pada alkohol. Pada $2950 \mathrm{~cm}^{-1}$ menunjukan $\mathrm{C}-\mathrm{H}$, sedangkan pada $3000-3700 \mathrm{~cm}^{-1}$ gugus $\mathrm{O}-\mathrm{H}$. Kadar makronutrien glukomanan umbi porang (Amorphophallus onchopyllus) meliputi: lemak sebesar $0,50 \%$, protein sebesar $1,05 \%$, serat sebesar $22,34 \%$, dan karbohidrat sebesar $31,33 \%$.

\section{UCAPAN TERIMA KASIH}

Terima kasih kami sampaikan kepada Lembaga Penelitian dan Pengabdian Kepada Masyarakat Sekolah Tinggi Ilmu Farmasi "Yayasan Pharmasi Semarang" yang telah membiayai penelitian dosen pemula tahun 2018.

\section{DAFTAR PUSTAKA}

An, N. T., Thien, D. T., Dong, N. T., Duna, P. L. And Du, N. V., 2011, Isolation and Characteristics of polysaccharide from Amorphophallus corrugatus in Vietnam, Carbohydrate Polym, j. Science direct 84, 64-68. 
Katsuraya, K., Okuyama, K., Hatanaka, K., Oshima K., Sato, T., dan Matsuzaki, K., 2003. Contitution of Konjac Glucomannan: Chemical Analysis and 13C NMR Spectroscopy. Carbohydrate polymers, $j$. Science direct, 53, 183-189.

Mulyono, E., Risfaheri, Misgiyarta, A.W, Permana, dan F. Kurniawan, 2009, Teknologi produkdi tepung mannan dari umbi iles-iles (Amorphophallus onchopyllus) yang dapat menghasilkan rendemen 85\% dan derajat putih 80\%. Makalah pada Seminar Hasil Penelitian SINTATA, 9-10 Oktober 2010, Badan Penelitian dan Pengembangan Pertanian, Jakarta.

Sande, A. M., Teijerio-Osorio, D., Remunan-Lopez, C., Alonso, M.J. 2009. Glucomannan, a Promising Polysaccharides for Biopharmaceutical Purposes. Eur. J. Pharm. Biophar, Vol 72, Issue 2, P:453-462

Standard Nasional Indonesia, 2009, Tepung terigu sebagai bahan makanan, SNI-01-3751-2009, Badan Standarisasi Nasional, Jakarta, 2.

Yenrina, R., 2015., Metode Analisis Bahan Pangan dan Komponen Bioaktif, Andalas University Press, Padang, hal 4, $39 \& 57$.

Widjanarko, S.B., Farrida, A. And Sutrisno, A., 2011, Effect of multi level Ethanol Leaching of physico-chemical properties of Konjac Flour (Amorphophallus onchophyllus), Technical Paper Conference, BITEC Bangna, Bangkok, Thailand, 16-18 June. 